\title{
Theoretical and practical aspects of sedentary behavior among medical professions in the field of dentistry - part I
}

Aspecte teoretice și practice ale comportamentului sedentar în rândul profesiilor cu profil medical din domeniul stomatologiei - partea I

\author{
Liliana Moraru' ${ }^{1}$ Viorel Perieanu², Mihai Burlibașa2 , Claudia-Camelia Burcea², \\ Mădălina Violeta Perieanu², Mădălina Adriana Malița² , Irina-Adriana Beuran², Mihai David², Oana \\ Eftene $^{2}$, Mihaela Chirila ${ }^{2}$, Ioana-Cristina Neagoe ${ }^{3}$, Magdalena Natalia Dina², Ioana Voinescu², \\ Elena Rabolu ${ }^{3}$, Valentin Daniel Sîrbu², Corina Marilena Cristache ${ }^{3}$ \\ ${ }^{1}$ Universitatea „Titu Maiorescu“, București, România \\ Universitatea de Medicină și Farmacie „Carol Davila“, București, România \\ "Universitatea „Dacia“, Pitești, România
}

\begin{abstract}
Sedentary behavior, both professional, occupational, and leisure, recreational, is one of the major risk factors for cardio-metabolic health and premature mortality.

But we find this sedentary behavior in many of the existing professional activities in 2021, among which are the professional activities with a medical profile in the field of dentistry: specific activities of the dental office (and here we discuss dentists and dental nurses) and activities specific to the dental technique laboratory (in this case, we are talking about dental technicians).
\end{abstract}

Keywords: sedentarism, dentists, dental nurses, dental technicians

\begin{abstract}
REZUMAT
Comportamentul sedentar - atât cel profesional, ocupațional, cât și cel de timp liber, recreațional - reprezintă unul dintre factorii de risc major ai sănătății cardio-metabolice și al mortalității premature.

Dar acest comportament sedentar îl regăsim în foarte multe dintre activitățile profesionale existente la nivelul anului 2021, printre acestea aflându-se și activitățile profesionale cu profil medical din domeniul stomatologiei: activități specifice cabinetului de stomatologie (și aici discutăm despre medicii stomatologi și despre asistentele medicale de cabinet) și activități specifice laboratorului de tehnică dentară (în acest caz, discutăm despre tehnicienii dentari).
\end{abstract}

Cuvinte cheie: sedentarism, medici stomatologi, asistenți/asistente de cabinet de stomatologie, tehnicieni dentari

\section{INTRODUCERE}

Comportamentul sedentar este foarte frecvent în multe dintre ocupațiile actuale, printre acestea numărându-se cele cu profil medical din domeniul stomatologiei care, datorită manoperelor pe care trebuie să le efectueze, cum sunt tratamentele dentare, tratamentele chirurgicale (manopere specifice cabinetului de stomatologie), realizarea dispoziti- velor protetice sau ortodontice (manopere cu o componentă mixtă, unele specific cabinetului de stomatologie, altele specifice laboratorului de tehnică dentară), de altfel, manopere mari consumatoare de timp, însă necesitând totodată și precizie extrem de mare, determină acești specialiști să-și petreacă majoritatea timpului în poziții fixe, vicioase, statice. 
Dar, când discutăm despre specialiștii care activează în acest domeniu medical al stomatologiei, discutăm în special despre medicii stomatologi și tehnicienii dentari, cei care alcătuiesc acele echipe robuste specifice acestei specialități (nu trebuie omise nici asistentele medicale de cabinet de stomatologie, fără de care activitatea specifică acestei profesii ar fi foarte mult îngreunată).

Mai mult decât atât, acești profesioniști petrec o proporție substanțială a vieții la locul de muncă. Momentul paradoxal în care trăim și în care societatea noastră este una „tehnofilă”, favorizează strategiile de evitare sau de minimizare a efortului fizic, cu petrecerea unei perioade tot mai mari de timp în comportamente sedentare recreaţionale, de la acestea nefăcând excepție nici profesioniștii domeniului stomatologic.

Prin urmare, specialiștii din domeniul stomatologiei reprezintă un grup țintă important pentru intervenții profilactice, privind îmbunătătirea activității fizice sau reducerea comportamentului sedentar.

În continuare, am realizat un material structurat în 2 părți, care se referă la multiple aspecte ale sedentarismului ce se pliază pe foarte multe structuri ocupaționale, dar se referă cu precădere, la profesiile medicale din domeniul stomatologiei: medici stomatologi, tehnicieni dentari, asistenți/ asistente medicale de cabinet de medicină dentară.

\section{COMPORTAMENTUL SEDENTAR ŞI INACTIVITATEA FIZICĂ - ASPECTE GENERALE}

Societatea postmodernă este caracterizată de creşterea gradului de dezvoltare și de progres. Progresul tehnologic a schimbat faţa societăţii, însă a creat condiţii ce pot periclita viaţa.

Astăzi, se discută din ce în ce mai mult despre sedentarism, ca factor de risc al stării de sănătate. Epidemie mondială, sedentarismul reprezintă o cauză aproape a tuturor bolilor, devenind obiectul diverselor studii, sensul termenului fiind descris sub două aspecte: comportament sedentar și inactivitate fizică. $\mathrm{Cu}$ toate că proveniența latină a termenului sedentar înseamnă literalmente a sta, acesta a fost utilizat de către cercetătorii din domeniul sănătății, pentru a se aprecia insuficiența activităţii fizice a unui individ (1).

Termenul ,sedentar” a fost iniţial utilizat, pentru descrierea comportamentelor care nu îndeplineau nivelurile de cheltuieli energetice echivalente unei activităţi fizice cu intensitate moderată. Mai mult, interesul a fost focusat asupra comportamen- telor sedentare de agrement, precum privitul la televizor şi utilizarea computerului în scop recreativ. Ulterior, comportamentele sedentare au devenit mai clar conturate, precizate, iar actualmente sunt clasificate raportându-se la nivelul cheltuielilor energetice, în manieră similară celei de clasificare a activităților fizice (2).

Comportamentul sedentar se referă la orice comportament de veghe cu o cheltuială energetică $\leq 1,5$ MET (echivalent metabolic), respectiv de efectuare a unor activități într-o poziție, precum așezat, decubit sau sprijinit, care necesită cheltuieli energetice foarte mici, apropiate de cele de odihnă. Comportamentul sedentar implică, aşadar, activitățile fizice cu un nivel foarte scăzut de cheltuieli energetice metabolice $(3,4)$.

Inactivității fizice i-a fost fost atribuită efectuarea unei cantități insuficiente de activitate fizică, adică nerespectarea ghidurilor (orientărilor) specifice privind activitatea fizică, respectiv $150 \mathrm{~min}$ de activitate fizică moderată - viguroasă pe săptămână sau 30 de minute de mers în ritm rapid, cinci zile pe săptămână, adică $\geq 3$ METS (5).

Dovezi recente susțin faptul că, atât comportamentul sedentar, cât și inactivitatea fizică, contribuie la cauza globală a bolii cronice. Acestea sugerează existența unui potențial prag de risc pentru sănătate, legat de gradul de activitate sau de inactivitate, fiind vorba, pe de o parte, de efectuarea activităților fizice o perioadă optimă de timp pentru a iniția și a susține efectele favorabile asupra sănătății, iar pe de altă parte, de alocarea comportamentului sedentar unei perioade optime de timp, dincolo de care este mult mai posibil să se instaleze boala cronică $(3,6)$.

Multe studii și cercetări efectuate cu privire la efectele negative ale activității fizice reduse au relevat o relație complexă, multifațetată, între activitatea fizică, consumul de energie (consumul caloric) și starea de sănătate. Dovezile epidemiologice recente demonstrează că, rezultatele pe termen lung ale comportamentului sedentar obișnuit (aşezat timp îndelungat) sunt diferite de cele asociate cu o lipsă de activitate fizică moderată până la viguroasă (exerciţii fizice de intensitate prea mică) asupra stării de sănătate. Este necesară o cantitate zilnică de stimulare neuromusculară, cu o oarecare combinație de durată și frecvență, pentru susținerea componentelor musculo-scheletale și metabolice (7).

Dacă componentele aparatului mio-artro-kinetic (mușchii, articulaţiile) și alte organe nu sunt solicitate, în timp apar tulburări funcţionale. Acest risc ne priveşte pe fiecare în aceeaşi măsură, însă 
un rol primordial îl ocupă persoanele, a căror activitate profesională impune menținerea unor anumite posturi timp îndelungat, așa cum se întâmplă în cazul specialiștilor din domeniul stomatologiei (medici stomatologi și tehnicieni dentari).

Comportamentul sedentar pare a fi o amenințare marcantă și omniprezentă pentru sănătatea publică, fiind astfel elaborate o serie de ghiduri, recomandări și mesaje conexe, privind descurajarea comportamentelor sedentare excesive (8).

$\mathrm{Cu}$ toate eforturile făcute în promovarea efectelor pozitive ale exerciţiului fizic regulat asupra sănătății, inactivitatea fizică nu numai că va continua să fie o problemă majoră, dar va deveni din ce în ce mai răspândită. În raportul din anul 2010 privind starea bolilor netransmisibile, Organizaţia Mondială a Sănătății (O.M.S.) a estimat că, milioane de oameni mor în fiecare an din cauza inactivității fizice, respectiv a unei activități fizice insuficiente, care nu întrunește condițiile necesare, ceea ce constituie al patrulea factor de risc important, care duce la deces în întreaga lume. Un număr din ce în ce mai mare de studii epidemiologice sugerează că, un comportament sedentar este asociat cu un risc crescut, pentru cel puțin 35 de boli cronice și creșterea ratei mortalității (9).

Comportament sedentar a crescut cantitativ odată cu nivelul de dezvoltare urbană, fiind denumit pe bună dreptate „,boala omului modern”. Problemei sedentarităţii îi pot fi atribuite nu numai lipsa de mișcare, ci și a stimulării oferite prin înlocuirea activităților.

Inactivitatea fizică s-a dovedit a fi mai frecventă la femei decât la bărbați, această tendință crescând odată cu vârsta. $\mathrm{O}$ treime dintre adulți și patru cincimi dintre tineri, nu ating nivelul recomandat de activitate fizică (2).

Inactivitatea fizică, potrivit Organizației Mondiale a Sănătății, este al patrulea factor de risc principal pentru mortalitatea globală, atribuit la $6 \%$ dintre decesele de la nivel mondial Studiile efectuate au demonstrat că, sedentarismul prelungit are consecințe dăunătoare asupra capacității funcționale atât în cazul subiecților sănătoși, cât și în cazul celor cu diverse afecțiuni (10).

Preocupările cercetătorilor privind impactul comportamentului sedentar asupra organismului uman au devenit tot mai intense astfel că, la sfârșitul anului 2017, aceștia au concluzionat că, riscul atribuit deceselor din cauza comportamentului sedentar poate fi mai mare, decât cel din cauza fumatului (11).

Un interes deosebit s-a acordat în ultimii ani atât comportamentului sedentar profesional, cât și comportamentului sedentar de timp liber, întrucât activitățile ocupaţionale și recreaționale, de agrement, alcătuiesc majoritatea orelor de veghe ale unei persoane adulte.

\section{FACTORI CE DETERMINĂ COMPORTAMENTUL SEDENTAR ŞI INACTIVITATEA FIZICĂ}

În ultimele decenii, a fost observată o schimbare a profilului de activitate al indivizilor, activitatea fizică viguroasă fiind înlocuită parţial de activitatea cognitivă. Mai mult, activitățile profesionale, dar și cele fizice zilnice, recreaționale, de agrement, se realizează prin utilizarea diverselor tehnologii.

Tehnologia a revoluționat lumea noastră, creând instrumente și resurse uimitoare, oferindu-ne informații utile la îndemâna noastră. Tehnologia modernă a deschis calea pentru dispozitive multifuncționale, portabile, din ce în ce mai rapid. Aceste dispozitive ne-au făcut viața mai ușoară, mai rapidă, mai bună și mai distractivă, dar ne-au adus cu sine şi noi condiţii şi circumstanţe care ne pot periclita viaţa, făcându-ne din ce în ce mai puțin mobili, cu motricitate tot mai redusă.

Astfel, organismul uman a fost supus la solicitări fizice din ce în ce mai mici, deoarece activitatea profesională, activităţile fizice zilnice sau activitățile recreaţionale nu mai necesită același efort fizic, toate acestea putându-se realiza, utilizând noile dispozitive tehnologice.

Rolurile sociale și familiale, locurile de muncă şi situațiile economice s-au schimbat, în timp fiind raportate de numeroase studii, ca factori ce influențează în mod direct comportamentul uman şi care au condus la creșterea perioadelor de timp petrecute în sedentarism.

Factorii care determină şi accentuează comportamentul sedentar includ: deplasările de acasă la locul de muncă și de la locul de muncă acasă, perioadele lungi de timp de menținere a unor posturi sau poziții incorecte de lucru, participarea la diverse întruniri, precum efecte asociate muncii, incluzând stresul și oboseala. Acestora li se adaugă și responsabilitățile familiale (5).

Activitatea musculară a diminuat foarte mult, crescând astfel comportamentul sedentar. De altfel, reducerea cheltuielilor energetice umane și creșterile comportamentului sedentar în ultimele câteva decenii, sunt deosebit de surprinzătoare la nivelul întregii societăţi (12).

În comparaţie cu alte profesii cu profil medical, cele din domeniul stomatologiei) atât activitate cli- 
nică, de cabinet de stomatologie, cât și activitate tehnică, de laborator de tehnică dentară) impun intervale mari de timp de menținere a corpului, în anumite poziții la locul de muncă. Aceste ședințe prelungite, în care sunt aplicate tratamentele medicale sau sunt efectuate diverse manopere, de realizare a pieselor protetice, limitează activitatea fizică, reducând astfel la minimum mișcarea și activitatea musculară.

Cantităţilor mari de timp petrecute în „nemișcare” la locul de muncă, li se adaugă și deplasările cu mașina. Dinamica evoluției tehnologice a redus activitatea fizică și acasă, și în comunitățile din care fac parte. Tehnologia a devenit o parte din ce în ce mai răspândită din viața de zi cu zi, contribuind la epidemia de comportament sedentar și inactivitate fizică. Toate aceste medii în care medicii dentiști, tehnicienii dentari și asistenții de cabinet de stomatologie își desfăşoară (petrec) activitățile pe parcursul unei zile, în majoritatea timpului, au un efect dublu asupra comportamentului acestora, adică se „mișcă” mai puțin și „stau” mai mult. $\mathrm{Cu}$ alte cuvinte, acestor specialiști le este destul de dificil să fie activi sau să-şi completeze programele zilnice, și așa destul de aglomerate, cu programe de exerciții fizice.

Atât condițiile de muncă (poziții de lucru, de menținere a unor posturi vicioase, incomode, pentru perioade mari de timp, efortul static prelungit, volumul de muncă etc.), cât și cele extraprofesionale, fac acești specialiști să adopte un comportament sedentar, considerându-1 uneori drept recompensă pentru odihnă sau pentru abordarea unor activități specifice (cititul, privitul la televizor, utilizarea computerului etc.). Astfel, comportamentului sedentar îi pot fi asociate atât interese, cât și nevoi sau confort și relaxare.

Profesia de medic dentist implică mulţi ani de studiu, programul de studii universitare având o durată de şase ani, acestuia adaugându-i-se rezidenţiatul, obținut în urma unui examen eliminatoriu extrem de sever, pentru a putea deveni medici specialiști, cu durate diferite, respectiv un număr de ani caracteristici fiecărei specialități din cadrul medicinei dentare. Câştigarea acestei educații este supusă multiplelor presiuni universitare/ academice, necesitând perioade lungi de timp, de menținere a poziției așezat. Cu toate cunoștințele despre stilul de viață sănătos, foarte mulți studenți și medici rezidenți resping opțiunile unei vieți sănătoase pentru obținerea educației, profesiei dorite.

Acest comportament sedentar este de multe ori păstrat și după finalizarea studiilor, munca cu pacienții necesitând menținerea unor posturi vici- oase, statice, perioade mari de timp, dar probabil și pentru că a devenit o obișnuință, fiind totodată un mod de obținere a relaxării sau a odihnei, în afara perioadelor de desfășurare a activităților profesionale.

Un lucru asemănător se întâmplă și în cazul tehnicienilor dentari, la care perioadele așezat pe scaun, ocupă cea mai mare a timpului unei zile. Dacă poziția așezat este menținută pe parcursul studenției perioade mari de timp pentru studiu și stagii practice, după încadrarea în câmpul muncii, aceasta va fi menținută perioade și mai mari de timp, pentru realizarea restaurărilor protetice de orice fel - fixe, mobile, mobilizabile, chirurgicale și a aparatelor ortodontice.

\section{COMPORTAMENTUL SEDENTAR ŞI INACTIVITATEA FIZICĂ - FACTORI DE RISC AI STĂRII DE SĂNĂTATE \\ Comportamentul sedentar şi inactivitatea fizică şi riscul de tulburări funcţionale mio-artro- kinetice}

În ultimele decenii, comportamentul sedentar și inactivitatea fizică, datorate marii industrializări și robotizări, au condus nu numai la dezvoltarea diferitelor boli cronice, precum diabetul de tip 2, bolile cardiovasculare, sindromul metabolic, osteoporoză, cancer etc., ci și la apariția unor tulburări musculo-scheletale, în special la nivelul coloanei cervicale, umerilor și regiunilor inferioare și superioare ale spatelui (coloană lombară și toracică superioară). Locurile de muncă moderne au schimbat natura ocupațiilor, trecându-se de la cele active la cele sedentare, care implică menținerea prelungită a poziției așezat, acest fapt datorându-se marii tehnologizări. Incidența mare a acestora în rândul persoanelor care își desfăşoară activitatea profesională în poziții așezat sau fixe timp îndelungat, posturi statice, la nivel mondial, se datorează atât absenței activității fizice, a lipsei de mișcare, precum și comportamentului sedentar adoptat (13).

Durerea de spate este una dintre cel mai frecvent întâlnite afecţiuni musculo-scheletale datorate sedentarismului, menținerii prelungite a poziției așezat, care provoacă durere, disconfort și dizabilitate, afectând atât bunăstarea mentală a persoanei, cât și eficiența acesteia în îndeplinirea sarcinilor profesionale și cotidiene, și, prin urmare, calitatea vieții.

S-a demonstrat, prin diverse studii efectuate, că durata menținerii poziţiei aşezat este direct proporțională cu durerea lombară joasă, aceasta re- 
prezentând a doua cauză de dizabilitate în Statele Unite ale Americii și a treia cauză la nivel mondial. De asemenea, s-a constatat prevalența mai mare la femei decât la bărbați, precum și incidența mai mare în rândul persoanelor supraponderale și obeze, cu un indice de masă corporală mai mare de $26,0 \mathrm{~kg} / \mathrm{m}^{2}(14,15)$.

Mai mult, comportamentul sedentar determină reducerea capacității discului intervertebral de a menține o concentrație normală de apă și astfel, diminuarea nivelului de hidratare al nucleului pulpos contribuie la dezvoltarea leziunilor degenerative și a celor de suprasarcină. De asemenea, stilul de viaţă sedentar poate fi un factor de risc pentru hernierea discului intervertebral. Persoanele cu un comportament sedentar pot dezvolta un complex de hiperlordoză flască, care duce la apariția durerii lombare (16).

Menținerea prelungită fie a poziției ortostatice, fie a poziției așezat reprezintă factori cauzali ai durerii articulațiilor membrelor inferioare. În poziție așezat, curburile coloanei vertebrale se abat de la normal, determinând devierea acesteia în plan sagital - cifoză sau în plan frontal - scolioză, provocând o presiune suplimentară asupra coloanei vertebrale, dar o mai mică presiune asupra articulaţiilor membrelor inferioare. În schimb, în poziția ortostatică, coloana vertebrală își păstrează curburile fiziologice și suportă mai puțină presiune, în timp ce membrele inferioare suportă mai multă presiune biomecanică, datorită greutății corpului (17).

Menținerea prelungită a coloanei vertebrale în poziții vicioase (cifoză, scolioză) vor influența funcția pulmonară, datorită efectelor gravitației asupra muşchiului diafragm, împiedicând mișcarea acestuia. Aceste posturi vicioase vor determina reducerea volumului pulmonar în timpul inspiraţiei, iar în expirație contracția musculară va deveni mai puțin eficientă.

Comportamentul sedentar împiedică dilatarea vaselor sangvine, conducând la oboseală musculară precoce și astfel la apariţia durerii și incoordonării musculare. Oboseala musculară crește susceptibilitatea de microtraumatisme și leziuni ale tendoanelor și ligamentelor. Un stil de viață sedentar determină diminuarea masei musculare și a vascularizării acesteia. Un comportament sedentar scade, de asemenea, eficiența neuromusculară, creștere gradul de hipotrofie a muşchilor scheletici și reduce forța musculară. Asocierea unei forțe musculare diminuate a membrelor inferioare (șoldului), va avea consecințe negative semnificative asupra controlului postural. Întrucât, menținerea controlului postural atât static, cât și dinamic este esențială pentru activităţile funcționale, la persoanele sedentare controlul postural fiind afectat, va exercita influențe negative asupra capacității acestora de a efectua activitățile zilnice în siguranță și în mod eficient, diminuând performanțele funcționale (18).

Comportamentul sedentar scade elasticitatea și masa musculară, determinând rigiditate musculară şi articulară. Apariţia rigidității musculare este determinată de scurtarea sarcomerelor - unitățile funcționale ale mușchilor striați în timpul inactivității, iar cea articulară este determinată de reducerea cantităţii de acid hialuronic - componentă principală a lichidului sinovial, care lubrifiază articulațiile și a cantității de sânge (19).

Osteoartrita și inflamația articulară pot fi, de asemenea, asociate cu stilurile de viaţă sedentare. Obezitatea este asociată cu osteoartrita, din cauza încărcărilor biomecanice mari pe cartilajul hialin intraarticular, la nivelul acestuia declanșându-se și dezvoltându-se procesul degenerativ, din cauza dezechilibrului ce apare între rezistența țesutului și forțele care exercită presiuni asupra lui $(19,20)$.

Dintre persoanele cele mai predispuse la apariția tulburărilor musculo-scheletale, fac parte cele din rândul profesiilor cu profil medical din domeniul stomatologiei (medici stomatologi, tehnicieni dentari, asistenți medicali de cabinet de stomatologie) care, datorită naturii muncii lor, petrec cea mai mare parte a timpului în anumite condiții care impun nemişcare, cu predominanța efortului static.

Specialiştii din domeniul tehnicii dentare fac parte dintr-un sector populațional, a căror activitate profesională se desfășoară în cea mai mare parte a zilei în poziție așezat. Prezența simptomatologiei afecțiunilor musculo-scheletale în rândul specialiștilor din domeniul stomatologiei atât la nivelul umerilor, spatelui - coloanei vertebrale, cât și la nivelul articulațiilor mari variază, ajungând până la $80 \%$. Aceastei incidențe crescute a afecțiunilor musculo-scheletale cu diferite localizări în rândul tehnicienilor dentari, îi sunt atribuite posturile de lucru incomode și statice și mişcările repetitive (21,22).

Un studiu transversal realizat pe studenţi ai diferitelor specialități din domeniul sănătăţii (medicină, farmacie, stomatologie și științe ale sănătății), a relevat prevalența afecțiunilor mio-artro-kinetice mai mare în rândul studenților din domeniul medicinei, decât al farmaciei și al științei sănătății. Cele mai afectate regiuni a corpului au fost la nivelul coloanei lombare, coloanei cervicale și porțiunii superioare a coloanei toracice. Studiul a menționat, 
de asemenea, că majoritatea studenților afectați aveau un nivel moderat de activitate fizică și că stresul psihosocial ar fi un contribuabil major al afectiunilor musculo-scheletale în rândul studenților de la medicină (23).

\section{Comportamentul sedentar şi riscul de boli cardiovasculare}

Activitatea fizică, făcând referire la orice mișcare corporală care este asociată cu cheltuielile de energie, acoperă întreg spectrul de activităţi, de la cele cu intensitate moderată sau viguroasă (exerciţii fizice), la activități cu intensitate mică (mers pe jos, activități de viață de zi cu zi). Beneficiile activităților fizice mici, moderate sau viguroase, au fost evaluate frecvent în ultimele decenii, în legătură cu prevenirea primară și secundară a bolilor cardiovasculare (24).

În ultimii ani însă, s-a dovedit existența unui interes din ce în ce mai mare, în studierea efectelor comportamentului sedentar asupra dezvoltării și progresiei bolilor cardiovasculare. Inactivitatea fizică și comportamentul sedentar au devenit o problemă majoră de sănătate publică, deoarece au fost asociate cu un risc crescut de morbiditate sau de agravare a multor boli cronice, acestea incluzând bolile cardiovasculare, insuficiența cardiacă congestivă, accidentul vascular cerebral etc. (25).

Boala cardiovasculară este principala cauză de deces în lume, în Statele Unite ale Americii, aceasta ucigând peste 600.000 de oameni în fiecare an (26).

Comportamentul sedentar și inactivitatea fizică sunt printre principalii factori de risc modificabili la nivel mondial, privind bolile cardiovasculare și mortalitatea cauzală. $\mathrm{Cu}$ toate eforturile făcute de Asociația Americană a Inimii, Colegiul American de Cardiologie și Colegiul American de Medicină Sportivă și alte organizații competente, de atenționare că atât comportamentul sedentar, cât și inactivitatea fizică sunt factori de risc majori ai bolilor cardiovasculare, nivelurile mari de comportament sedentar şi nivelurile mici de activitate fizică sunt frecvent întâlnite la nivelul populației Statelor Unite ale Americii și a întregii lumi. Studiile epidemiologice efectuate, privind asocierile dintre comportamentul sedentar și diverse afecţiuni au relevat că, cea mai frecventă asociere a fost între comportamentul sedentar și mortalitatea prin bolile cardiovasculare. De asemenea, rezultatele unei metaanalize confirmă creșterea riscului de boli cardiovasculare, asociat cu comportamentul sedentar (27).

Numeroasele cercetări efectuate au demonstrat că, inactivitatea și comportamentul sedentar este legat de mai mulți factori de risc ai bolii cardiovasculare, inclusiv sindromul metabolic, hipertensiunea arterială și diabetul zaharat tip 2. A fost raportată, de asemenea, o asociere semnificativă între comportamentul sedentar și incidența bolii cardiovasculare și mortalitatea de toate cauzele, chiar și atunci când se efectuează nivelurile de activitate fizică moderată până la viguroasă, sugerând că implicarea în niveluri adecvate de activitate fizică nu protejează pe deplin indivizii de efectele dăunătoare, nocive ale comportamentului sedentar. Mai mult decât atât, s-a demonstrat că, efectele comportamentului sedentar recreațional sunt mai nocive, fiind găsită o asociere mai mare cu factorii de risc cardiovasculari - creșteri ale nivelului de proteină C - reactivă, fibrinogen, lipide în sânge și creșteri ale adipozităţii, comparativ cu efectele comportamentului sedentar profesional (28).

\section{Comportamentul sedentar şi riscul de diabet zaharat tip 2}

Studiile efectuate privind asocierea comportamentului sedentar și riscul de diabet zaharat de tip 2 au demonstrat o creștere marcată a nivelului plasmatic de insulină, indicând o rezistență crescută la insulină. Un rezultat remarcabil al acestor studii a fost rapiditatea cu care organismul uman se transformă, fiindu-i suficiente câteva săptămâni, fără nicio intervenție asupra dietei și a nivelului de activitate, pentru a suferi o afectare metabolică considerabilă, creșteri ale nivelurilor markerilor fiziologici și mai importante putând apărea după 6 luni de comportament sedentar prelungit. Cercetările au indicat faptul că, nu există o ,cantitate acceptabilă" reală de inactivitate fizică prelungită, deoarece durează relativ puțin, pentru manifestarea consecințelor asupra sănătății. De asemenea, aceste studii și cercetări indică o incidență mai mare a diabetului de tip 2, asociat comportamentului sedentar prelungit în rândul persoanelor de gen feminin (29).

Un studiu exrem de interesant a relatat că, divizarea comportamentului sedentar prelungit la fiecare 30 de minute, introducând timp de 3-5 minute exerciții cu rezistență sau mers ușor, reduce nivelul de glucoză și insulină în următoarele ore atât la persoanele sănătoase, cât și la cele diabetice (30).

Comportamentul sedentar și riscul de obezitate

Pandemie mondială, obezitatea a fost asociată schimbărilor sociale, de mediu, reducerii substanțiale a comportamentului activ (a timpului petrecut în mod activ fizic) și creșterea comportamentului sedentar (a timpului petrecut în mod sedentar), în primul rând datorită evoluției multime- 
dia - internet, telefonie mobilă și a utilizării autovehiculelor pentru deplasări. La nivel mondial, s-au înregistrat anual creșteri semnificative ale indicelui de masă corporală în rândul populaţiei, incidența supraponderalităţii și obezităţii crescând dramatic. Obezitatea a devenit, așadar, o problemă majoră de sănătate publică în întreaga lume. Potrivit O.M.S. (Organizația Mondială a Sănătății), milioane de adulți mor în fiecare an din cauza obezităţii și supraponderalității, iar incidența la nivel mondial a crescut semnificativ în ultimii ani, cu toate că au existat și perioade de descreștere a acesteia (31).

Un studiu transversal realizat pe un eșantion de adulți sănătoși, a demonstrat asocierea comportamentului sedentar, ca modalitate de petrecere a timpului liber, recreațional, cu un indice de masă corporală mare și risc de obezitate (32).

Studiile experimentale efectuate au demonstrat că, o creștere a comportamentului sedentar este asociată cu cheltuieli reduse de energie, dezvoltarea rezistenței la insulină și acumularea de grăsimi corporale. În dezvoltarea epidemiei contemporane de obezitate au fost implicaţi multiplii factori, însă schimbarea stilului de viață, de la cel activ fizic la cel sedentar, a reprezentat unul dintre factorii cheie. Creșterile dramatice ale utilizării multimedia (computer, televiziune, internet), utilizarea autovehiculelor pentru deplasări și diminuarea substanțială a numărului de profesii intense fizic au condus la reduceri ale cheltuielilor energetice, în timp ce consumul excesiv de alimente nesănătoase a dus la creșterea aportului de energie. Chiar şi unele mici schimbări individuale pot conduce la dezechilibrul energetic sistematic, adică aportul energetic să depășească consumul energetic și astfel să apară supraponderea sau obezitate (31).

Excesul de greutate, respectiv supraponderea și obezitatea şi adoptarea unui comportament sedentar pe perioade lungi de timp au fost asociate cu mortalitate crescută și boli cronice, precum diabet zaharat tip 2, sindrom metabolic, boli cardiovasculare, osteoporoză și unele tipuri de cancer (32).

Activitatea profesională a medicilor dentiști, a asistenţilor de stomatologie și a tehnicienilor dentari necesită un nivel scăzut de cheltuieli energetice, iar asocierea unui comportament sedentar profesional cu un comportament sedentar recreaţional, plus un regim alimentar hipercaloric, contribuie în mod sigur la creșterea greutăţii corporale, cu acumulare de țesut adipos, ceea ce poate avea consecințe negative asupra sănătății acestor specialiști.

\section{Comportamentul sedentar şi riscul de osteoporoză}

Efectul comportamenului sedentar asupra țesutului osos a fost dezbătut în multe studii, acestea relevând efectul dăunător al acestuia asupra oaselor. S-a constatat că, factorii stilului de viață influențează masa osoasă maximă a adulților, activitatea fizică optimizând acumularea acesteia, în timp ce un comportament sedentar prelungit accelerează resorbția osoasă şi diminuează formarea sa (33).

Osteoporoza, boală scheletică sistemică caracterizată de reducerea masei osoase şi deteriorarea microarhitecturii ţesutului osos, este frecvent întâlnită la pesoanele de vârsta a treia, în special la persoanele de gen feminin. Atrofia osoasă, care afectează cele două componente ale osului - substanţa organică şi substanţa minerală - predispune la fragilitate osoasă şi la creșterea riscului de fracturi. Din cauza fracturilor patologice pe care le determină - fracturi de col femural, fracturi ale extremității distale a radiusului, fracturi ale extremității superioare a radiusului, fracturi ale coloanei vertebale, fracturi ale coastelor - osteoporoza reprezintă o majoră sursă de morbiditate și mortalitate (34).

Cercetările efectuate au relatat eficacitatea exercițiului fizic la sectorul populațional vârstnic, ca o modalitate de a reduce riscul de fracturi. De asemenea, acestea susțin că femeile cu osteopenie/ osteoporoză au avut un comportament sedentar mai prelungit, comparativ cu bărbații, fiind implicate în activități fizice de intensitate mai mică și mult mai puțin în activități fizice de intensitate moderată și viguroasă, în timp ce bărbații au fost implicați în mai multe activități fizice de intensitate moderată şi viguroasă și în mai puține activităţi fizice de intensitate mică, cu un comportament sedentar cu mult mai redus, decât în cazul femeilor. De remarcat, în studiile efectuate a fost, de asemenea, faptul că, în cazul femeilor aflate la menopauză, reducerea comportamentului sedentar a fost asociată cu risc mai mic de osteopenie și osteoporoză la nivelul colului femural. Însă, scăderea masei osoase fiind strâns legată de activitatea endocrină se realizează diferit și în funcție de sexul persoanei, astfel, la sexul bărbătesc, scăderea masei osoase se realizează în mod lent și constant, în timp ce, la sexul femeiesc, scăderea masei osoase se realizează în mod inegal $(35,36)$.

\section{Comportamentul sedentar şi riscul de depresie şi anxietate}

Potrivit Organizației Mondiale a Sănătății, sănătatea mintală este definită ca fiind o stare de bu- 
năstare, în care fiecare individ își realizează propriul potențial și care poate face față tensiunilor normale ale vieții, poate lucra productiv și rodnic, fiind capabil să contribuie la comunitatea sa. Studiile efectuate au relevat o diferență substanțială și semnificativă statistic, în ceea ce privește bunăstarea mintală între subiecții care nu au efectuat activităţi fizice (exerciţii fizice), comparativ cu cei care au efectuat activități fizice, indiferent de intensitatea acestora, moderată sau viguroasă, aceștia din urmă beneficiind de o bunăstare mintală mult superioară (37).

Extrem de frecvente în viaţa de zi cu zi, comportamentele sedentare au fost și vor rămâne probabil mult timp obiectul multor studii și cercetări. În prezent, nu s-a stabilit o precizare clară a comportamentelor sedentare pasive și active din punct de vedere mental. A viziona emisiuni TV, a asculta, a face conversație în poziție așezat sunt considerate comportamente pasive din punct de vedere mental. A utiliza un computer, a citi o carte sau un ziar, a conduce o maşină, a participa la o întâlnire, a tricota sau a coase sunt considerate comportamente active din punct de vedere mental. Pe lângă impacturile negative asupra sănătății fizice, crescând riscul de boli cronice (afectiuni musculo-scheletale, boli cardiovasculare, diabet zaharat de tip 2, osteoporoză, cancer etc.), comportamentului sedentar i-au fost asociate tulburări ale sănătății mintale, precum stresul, anxietatea, depresia, tulburări de

Conflict of interest: none declared

Financial support: none declared

\section{BIBLIOGRAFIE}

1. Saunders TJ, Chaput JP, Tremblay MS. Sedentary behaviour as an emerging risk factor for cardiometabolic diseases in children and youth. Can J Diabetes. 2014;38:53-61.

2. Raynor HA, Bond DS, Freedson PS, Sisson SB. Sedentary behaviors, weight, and health and disease risks. J Obes. 2012;2012:852743.

3. González K, Fuentes J, Márquez JL. Physical inactivity, sedentary behavior and chronic diseases. Korean J Fam Med. 2017; 38(3):111-115.

4. Thivel D, Tremblay A, Genin PM et al. Physical activity, inactivity, and sedentary behaviors: Definitions and implications in occupational health. Front Pub Health. 2018;6:288.

5. Rawlings GH, Williams RK, Clarke DJ, et al. Exploring adults' experiences of sedentary behaviour and participation in nonworkplace interventions designed to reduce sedentary behaviour: a thematic synthesis of qualitative studies. BMC Public Health. 2019;19(1):1099.

6. Genin PM, Dessenne P, Finaud J, et al. Effect of work-related sedentary time on overall health profile in active vs. inactive office workers. Frontiers Public Health. 2018;6:279.

7. Owen N, Sparling PB, Healy GN et al. Sedentary behavior: Emerging evidence for a new health risk. Mayo Clinic Proceedings. 2010;85(12):1138-1141.

8. Tremblay MS. The consequences of sedentary behaviors: Keeping interpretations anchored in evidence. Exerc Sport Sci Rev. 2018;46(1):4. somn, insomnii, demența. Aceste tulburări pot provoca o varietate mare de probleme atât din punct de vedere emoțional, cât și din punct de vedere fizic, cu repercusiuni negative asupra capacității de desfășurare a activității profesionale, a celei familiale și sociale, diminuând astfel calitatea vieții persoanei. Studiile efectuate cu privire la efectele comportamentelor sedentare active și pasive din punct de vedere mental au demonstrat că, cele pasive mental au un efect negativ asupra sănătății, în schimb cele active mental au un efect favorabil asupra sănătătiii, constatându-se asocierea pozitivă dintre comportamentul sedentar, în special a celui pasiv mental cu riscul de depresie, precum și că trecerea de la un comportament sedentar pasiv mental la unul activ mental poate reduce riscul de anxietate și depresie $(38,39)$.

\section{CONCLUZIE}

Comportamentul sedentar - atât cel profesional, ocupaţional, cât și cel de timp liber, recreaţional - reprezintă unul dintre factorii de risc major ai sănătății cardio-metabolice și ai mortalităţii premature.

\section{Notă}

Toți autorii au avut contribuții egale cu primul autor.

9. Thyfault JP, Du M, Kraus WE, et al. Physiology of sedentary behavior and its relationship to health outcomes. Med Sci Sports Exerc. 2015;47(6):1301-1305.

10. Fenton SAM, Veldhuijzen van Zanten JJCS, Kitas GD et al. Sedentary behaviour is associated with increased long-term cardiovascular risk in patients with rheumatoid arthritis independently of moderate-to-vigorous physical activity. BMC Musculoskelet Disord. 2017;18(1):131.

11. Koh D. Sedentary behaviour at work - an underappreciated occupational hazard? Occupational Medicine. 2018;68(6):350-351.

12. Panahi S, Tremblay A. Sedentariness and health: Is sedentary behavior more than just physical inactivity? Frontiers Public Health. 2018;6:258.

13. Danquah IH, Kloster S, Holtermann A, et al. Effects on musculoskeletal pain from „Take a stand!” - A cluster-randomized controlled trial reducing sitting time among office workers. Scand J Work Environ Health. 2017:43(4):350-357.

14. Hanna F, Daas RN, El-Shareif TJ, et al. The relationship between sedentary behavior, back pain, and psychosocial correlates among university employees. Frontiers Public Health. 2019;7:80.

15. Bontrup C, Taylor WR, Fliesser M, et al. Low back pain and its relationship with sitting behaviour among sedentary office workers. Appl Ergon. 2019;81:102894.

16. Citko A, Górski S, Marcinowicz L, Górska A. Sedentary lifestyle and nonspecific low back pain in medical personnel in North-East Poland. BioMed Research International. 2018;2018:1965807. 
17. Daneshmandi H, Choobineh A, Ghaem H, Karimi M. Adverse Effects of Prolonged Sitting Behavior on the General Health of Office Workers. J Lifestyle Med. 2017;7(2):69-75.

18. Alsufiany MB, Lohman EB, Daher NS, et al. Non-specific chronic low back pain and physical activity: A comparison of postural control and hip muscle isometric strength: A cross-sectional study. Medicine (Baltimore). 2020;99(5):e18544.

19. Lurati AR. Health issues and injury risks associated with prolonged sitting and sedentary lifestyles. Workplace Health \& Safety. 2018; 66(6):285-290.

20. Brandt KD, Dieppe P, Radin E. Etiopathogenesis of osteoarthritis. Rheum Dis Clin North Am. 2008;34(3):531-59.

21. Burcea CC, Georgescu L, Burlibașa M, et al. Chestionar destinat orientării strategiei de intervenție profilactică și terapeutică în scopul creșterii performanți la locul de muncă a specialiștilor din domeniul tehnicii dentare. În: Burcea CC, Ionescu C. Cristache CM, Burlibaşa L. Probleme în medicină și biologie, Vol. 2, București: Ed. Ars Docendi, 2014;11-62.

22. Burcea CC, Georgescu L, Malița M, Comes CA. Identificarea problemelor aparatului locomotor legate de activitatea profesională a practicienilor în medicina dentară - Studiu preliminar. În: Pădure L, Marcov EC, Burcea CC, Lupușoru M. Actualități în asistența medicală, Vol. IV, București: Ed. Ars Docendi, 2013:265-341.

23. Hendi OM, Abdulaziz AA, Althaqafi AM et al. Prevalence of musculoskeletal disorders and its correlation to physical activity among health specialty students. Int J Prev Med. 2019;10:48.

24. Carter S, Hartman Y, Holder S et al. Sedentary behavior and cardiovascular disease risk: Mediating mechanisms, exercise and sport. Sciences Reviews. 2017;45(2): 80-86.

25. Warren TY, Barry V, Hooker SP, et al. Sedentary behaviors increase risk of cardiovascular disease mortality in men. Med Sci Sports Exerc. 2010;42(5):879-885.

26. Silfee V, Lemon S, Lora V, Rosal M. Sedentary behavior and cardiovascular disease risk factors among Latino adults. $J$ Health Care Poor Underserved. 2017;28(2):798-811.

27. Lavie CJ, Ozemek C, Carbone S, et al. Sedentary behavior, exercise, and cardiovascular health. Circ Res. 124(5):799-815.

28. Garcia JM, Duran AT, Schwartz JE, et al. Types of sedentary behavior and risk of cardiovascular events and mortality in blacks: The Jackson heart study. J Am Heart Assoc. 2019;8(13):e010406.
29. Fox M. What is sedentarism? J Acad Nutr Diet. 2012;112(8): P1127.

30. Moghetti P, Bacchi E, Dona S. Metabolic effect of breaks in sedentary time in subjects with type 2 diabetes. Current Opinion in Endocrine and Metabolic Research. 2019;9:40-44.

31. Youngwon K. Sedentary lifestyle and obesity in adults. Graduate Theses and Dissertations. lowa State University. 2015; 14415. Available at: https://lib.dr.iastate.edu/cgi/viewcontent. cgi?article $=5422 \&$ context $=$ etd.

32. Heinonen I, Helajärvi H, Pahkala K et al. Sedentary behaviours and obesity in adults: The cardiovascular risk in young Finns study. BMJ Open. 2013;3(6):e002901.

33. Koedijk JB, van Rijswijk J, Oranje WA, et al. Sedentary behaviour and bone health in children, adolescents and young adults: A systematic review. Osteoporos Int. 2017;28(9):2507-2519.

34. Burcea CC, Georgescu L, Burlibașa M, et al. Evaluarea stării de sănătate și a calității vieții la persoanele de vârsta a treia. În: Burcea CC, Perienu VS, Dumitru SG, Burlibașa L. Actualități în asistența medicală, Vol. 7. București: Ed. Ars Docendi, 2016:12-60.

35. Braun S, Kim Y, Jetton A et al. Prediction of bone mineral density and content from measures of physical activity and sedentary behaviour in younger and older females. Prev Med Rep. 2015;2:300-305.

36. Rodríguez-Gómez I, Mañas A, Losa-Reyna J et al., Associations between sedentary time, physical activity and bone health among older people using compositional data analysis. PloS One. 2018;13(10):e0206013.

37. Harris MA. The relationship between physical inactivity and mental wellbeing: Findings from a gamification-based community-wide physical activity intervention. Health Psychol Open. 2018;5(1):2055102917753853.

38. Huang Y, Li L, Gan Y et al. Sedentary behaviors and risk of depression: A meta-analysis of prospective studies. Transl Psychiatry. 2020;10(1):26

39. Pengpid S, Peltzer K. High sedentary behaviour and low physical activity are associated with anxiety and depression in Myanmar and Vietnam. Int J Environ Res Public Health. 2019;16(7):1251. 